\title{
Electrocardiographic Pattern of Agoutis (Dasyprocta prymnolopha) Chemically Contained by the Association of Ketamine and Xylazine
}

\author{
Osmar Ferreira da Silva Filho', Gerson Tavares Pessoa ${ }^{2}$, Renan Paraguassu de Sá Rodrigues ${ }^{1}$, \\ Andrezza Braga Soares da Silva', Laecio da Silva Moura', Francisco das Chagas Araújo Sousa', \\ Maria Angélica Parentes da Silva Barbosa', Jacyara de Jesus Rosa Pereira Alves ${ }^{4}$, \\ Kassio Vieira Macedo ${ }^{5}$ \& Flávio Ribeiro Alves ${ }^{6}$
}

\begin{abstract}
Background: The agouti (Dasyprocta prymnolopha, Wagler, 1831) is an existing wild rodent in almost all of Brazil, used as a biological model in several scientific studies. Veterinary cardiology has showed great advances in the diagnostic area due to the possibility of cardiac evaluation by non-invasive methods. For the practice of scientific or handling procedures in wild animals, chemical containment is essential. Thus, it is important to know the effect of anesthetic protocols on the cardiovascular system, observed through complementary tests, such as the electrocardiogram. The objective of this study was to describe the computerized electrocardiographic tracing of agoutis chemically contained by the association of Ketamine and Xylazine.

Materials, Methods \& Results: Eighteen male and female clinically healthy animals, aged among 2 years, submitted to digital electrocardiographic examination, were used. The device used to obtain the tracing was the veterinary electrocardiograph (Electrocardiogram Acquisition Module for Computer) - Brazilian Electronic Technology (TEB). The analysis was always made from derivation II (DII). Chemical containment was performed by the combination of Ketamine and Xylazine, intramuscularly. The results showed that the heart rate for males was on average $113.25 \mathrm{bpm}$, while for females the value of $124.60 \mathrm{bpm}$ was observed, and there was no significant difference between the genders $(P>0.05)$. The mean weight of males was $2.31 \mathrm{~kg}$ and for females $2.28 \mathrm{~kg}$; there was no statistical difference for this variable $(P>0.05)$. For the QRS duration of $46.14 \pm 5.05 \mathrm{~ms}$ (males) and $44.66 \pm 5.94 \mathrm{~ms}$ (females) and PR interval of $79.94 \pm 12.01 \mathrm{~ms}$ (males) and $84.29 \pm 12.37 \mathrm{~ms}$ (females), there was no statistical difference $(P>0.05)$. The amplitude of the $\mathrm{R}$ wave of $0.42 \pm 0.31$ $\mathrm{mV}$ (males) and $0.36 \pm 0.22 \mathrm{mV}$ (females) showed no statistical difference $(P>0.05)$. The $\mathrm{T}$ wave showed itself both negative (10 animals) and positive ( 8 animals), with amplitude measured at $0.24 \pm 0.16 \mathrm{mV}$ for males and $0.25 \pm 0.10 \mathrm{mV}$ for females $(P>0.05)$. The anesthetic protocol was well tolerated by the animals of this experiment, and there were no episodes of arrhythmias during the time of their monitoring.

Discussion: Wild animals, in general, need chemical containment, with a view to reducing stress during scientific and handling procedures. The protocols established in this work can be used in future experiments which require a longer handling time. The values found for heart rate (HR) of anesthetized agoutis were lower than those for non-anesthetized agoutis, proving the influence of the stress during retention and the depressant cardiovascular effect of the anesthetic drug used. The electrocardiographic parameters and the tracing morphology of the agoutis were like the results found for anesthetized small rodents. The QT interval was higher in males than in females, justifying the fact that it could be influenced by variations in HR, which also showed superior results for males. Taking into consideration the morphological similarity between different individuals, the QT interval in anesthetized agoutis did not present significant differences between the genders, a characteristic also found in ferrets. The animals of this experiment were submitted to food fasting, a fact that contributed to a better standardization of the experiment, preventing alterations in the morphology of the QRS complex, which could lead to changes in the measurements.
\end{abstract}

Keywords: wild animals, rodents, anesthesia, cardiology.

${ }^{1}$ Animal Science Post-Graduate Program \& ${ }^{2}$ Medical Residence in Veterinary Image Diagnosis, Federal University of Piauí (UFPI), Teresina, PI, Brazil. ${ }^{3}$ Department of Medicine, Faculty of Medical Science, State University of Piauí, (UESPI), Teresina. ${ }^{4}$ Coloproctology and Colorectal Surgery Service of the University Hospital \& ${ }^{5}$ Health Science Post-Graduate, UFPI, Teresina. ${ }^{6}$ Department of Veterinary Morphophysiology, UFPI, Teresina. CORRESPONDENCE: F.R. Alves [flavioribeiro@ ufpi.edu.br - Tel.: +55 (86) 3215-5757]. Department of Veterinary Morphophysiology, Federal University of Piauí - UFPI. CEP 64049-550 Teresina, PI, Brazil. 


\section{INTRODUCTION}

The agouti (Dasyprocta prymnolopha, Wagler, 1831) is a small mammal rodent found in almost all Brazilian territory [19], which has been shown to be an important animal model for scientific studies, including those for cardiovascular evaluation [7,32].

Veterinary cardiology has presented great advances in the area of diagnosis by the possibility of performing examinations of the heart by non-invasive methods $[1,23]$. Among these tests, electrocardiography, a low-cost and easy-to-perform technique [7], stands out.

For veterinary, scientific or handling procedures in wild animals, chemical containment is almost always necessary [12]. Among the most commonly used anesthetic drugs for this function, Xylazine, which diffused widely in anesthetic procedures in wild animals, is noteworthy for ease of administration and for allowing association with other agents [38]. Among these, the association Xilazine and Ketamine has been widely used due to the analgesic, myorelaxant and sedative properties of Xylazine [11,29], related to a high lethal dose of Ketamine, allowing its use without the exact knowledge of the animal's weight [17].

Due to the need of chemical restraint for wild animal handling and knowing the wide existing drug association, this study aimed to describe the electrocardiographic tracing of the agoutis (Dasyprocta prymnolopha) contained by the association of Ketamine and Xylazine.

\section{MATERIALS AND METHODS}

\section{Animals}

Eighteen agoutis (Dasyprocta prymnolopha) were randomly assigned to two groups, consisting of 09 males and 09 females, approximately two years old and weighing between 1.5 and $2.3 \mathrm{~kg}$, from the Center for Studies and Preservation of Wild Animals (NEPAS), Federal University of Piauí (UFPI), Teresina, Piauí, Brazil.

The protocols used in this experiment were approved by the Committee on Ethics in Animal Experimentation - CEAA / UFPI (No 0117 / 2010) and authorized by the Ministry of the Environment, through the System of Authorization and Information of Biodiversity - SISBIO of the Brazilian Institute of the Environment and Natural Renewable Resources IBAMA (No 26101 - 1).
The agoutis were considered healthy by hematological examination, serum biochemist, considering liver and renal function and echocardiographic examination.

\section{Anesthetic Protocol}

The animals were pre-prepared with a $12 \mathrm{~h}$ solid fasting and $6 \mathrm{~h}$ liquid one. When they were captured in their enclosures with dip nets and physically restrained, $40 \mathrm{mg} / \mathrm{kg}$ of Ketamine Hydrochloride ${ }^{1}$ and $1 \mathrm{mg} / \mathrm{kg}$ of Xylazine Hydrochloride ${ }^{2}$ were given intramuscularly. This protocol allowed time for the tests to be carried out and in none of the animals there was need for reapplications.

\section{Electrocardiographic examination}

To perform the tests the animals were positioned in the right lateral decubitus, with the parallel limbs extended and perpendicular to the long axis of the body, on a table with rubber insulating surface to avoid interferences.

The electrocardiographic exams were initiated as soon as the anesthetic action was observed, on average 5 to $10 \mathrm{~min}$ after the application of the anesthetic agents. The animals were monitored at the electrocardiographic exam for $45 \mathrm{~min}$.

The device used to obtain the tracing was a Veterinary Electrocardiograph ${ }^{3}$. The tracings were stored on the computer's hard disk and then analyzed and the measurements taken on the computer itself. The distribution of the electrodes followed the methodology standardized by Willen Eithoven, with the right and left thoracic electrodes positioned above the olecranon in their caudal aspect and the right and left pelvic electrodes above the patellar ligaments in the cranial aspect of each pelvic limb. The velocity used for the records was $25 \mathrm{~mm} / \mathrm{s}$, with a voltage calibration of $1 \mathrm{~cm}$ for each millivolt $(1 \mathrm{~cm}=1 \mathrm{mV})$, thus obtaining standard electrocardiographic leads, which were obtained through the potential difference between the electrodes.

The electrocardiographic records were performed in the bipolar leads, DI, DII, DIII, aVR, aVL, aVF, and unipolar precordial chest leads, rV2, V2, V4 and V10 (Figures 1 and 2). The analyzes were always made from derivation II (DII) [Figure 3]. It was analyzed and measured the duration (milliseconds-ms) and amplitude (millivolts-mV) of the $\mathrm{P}$ wave, the interval duration of the PR (ms) and of the QRS complex (ms); the amplitude of the $\mathrm{R}$ wave $(\mathrm{mV})$, the ST segment leveling, the QT interval duration (ms), the $\mathrm{T}$ wave polarity and the rhythm and heart rate (bpm) [45]. 


\section{Statistical analysis}

The data were submitted to the error normality test (Shapiro-Wilk and Kolmogorov-Smirnov test) and afterwards the means of the groups were analyzed by paired Student's $t$-test for the interpretation of the parameters, considering a confidence interval of $5 \%(P<0.05)$.

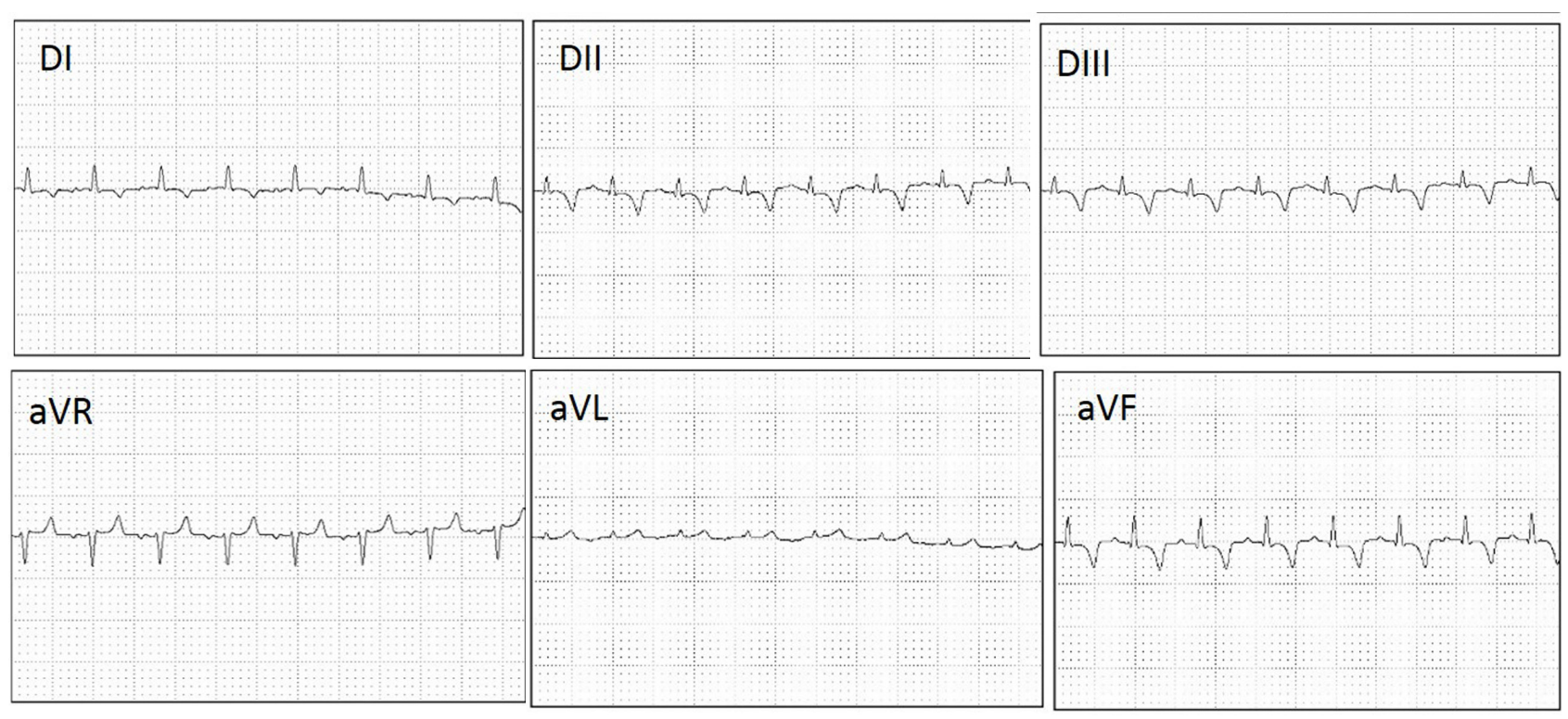

Figure 1. Electrocardiogram record of a clinically normal agouti (Dasyprocta prymnolopha), sedated with Xylazine Hydrocloride (40 mg/kg/IM) and Ketamine Hydrocloride ( $1 \mathrm{mg} / \mathrm{kg}$ IV). Record speed: $25 \mathrm{~mm} / \mathrm{s}, 1 \mathrm{~cm}=1 \mathrm{mV}$, in the bipolar and unipolar leads (DI, DII, DIII, aVR, aVL, aVF).
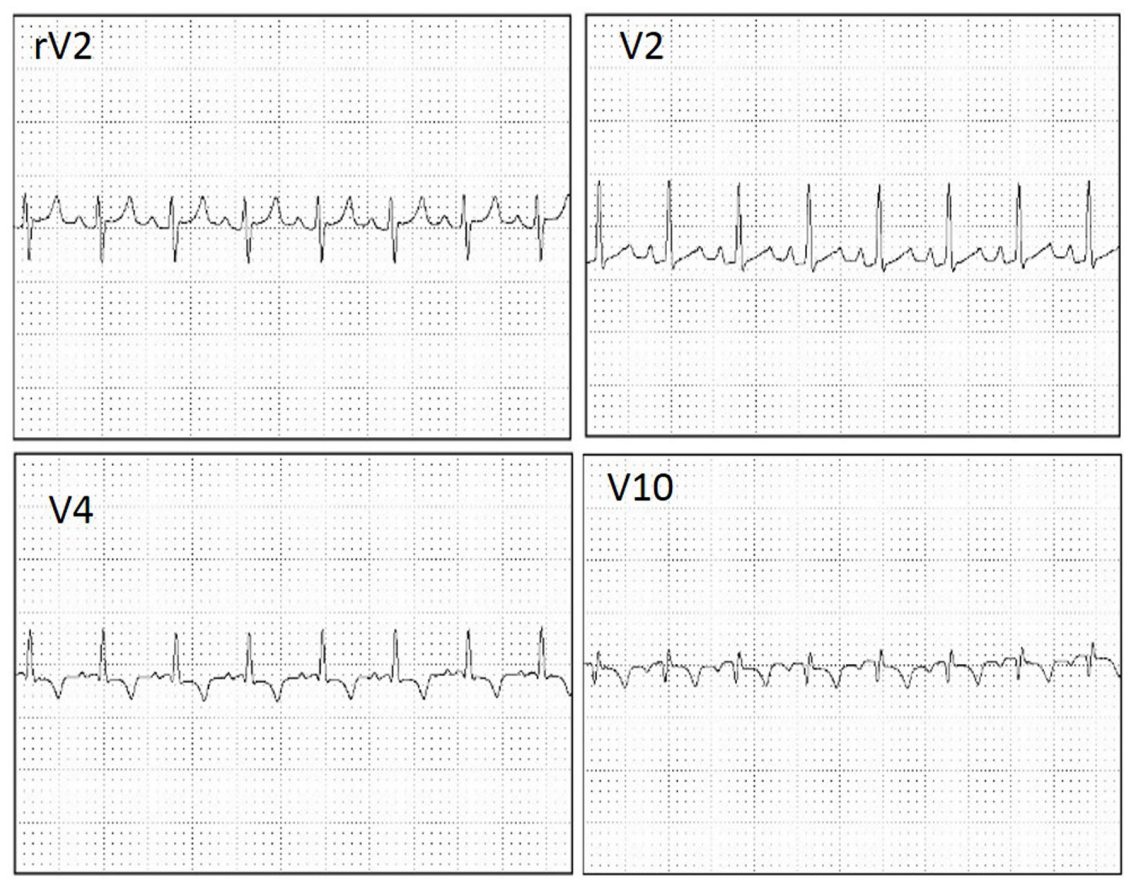

Figure 2. Electrocardiogram record of a clinically normal agouti (Dasyprocta prymnolopha), sedated with Xylazine Hydrocloride ( $40 \mathrm{mg} / \mathrm{kg} / \mathrm{IM}$ ) and Ketamine Hydrocloride ( $1 \mathrm{mg} / \mathrm{kg}$ IV). Record speed: $25 \mathrm{~mm} / \mathrm{s}, 1 \mathrm{~cm}=1 \mathrm{mV}$, in the unipolar precordial chest leads (rV2, V4, V10). 


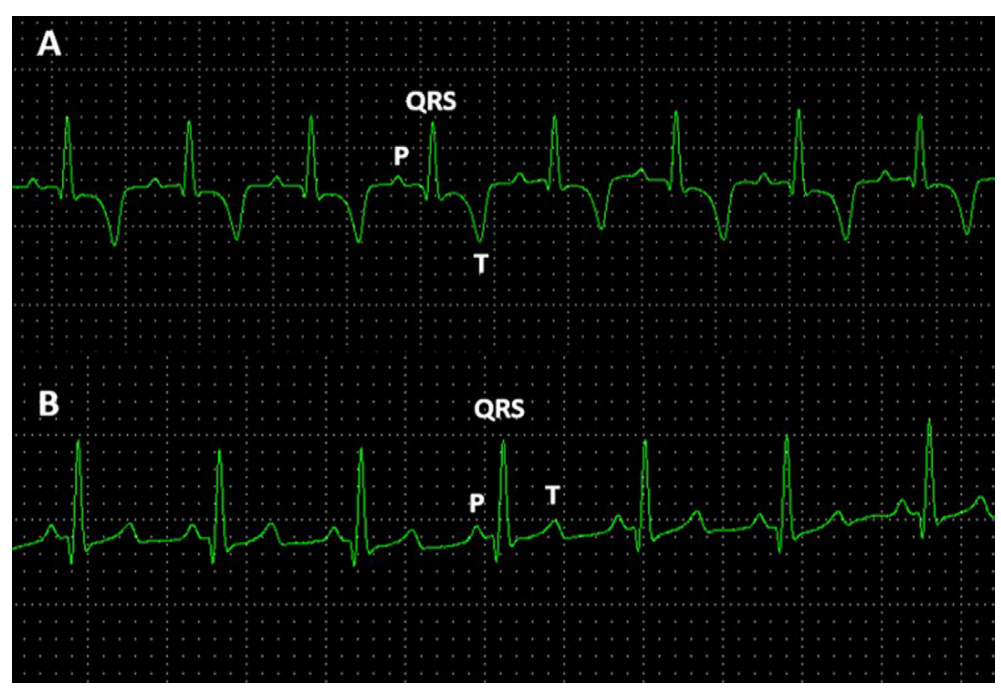

Figure 3. Normal digital electrocardiographic tracing, recorded in DII leads, of the agoutis (Dasyprocta prymnolopha), contained chemically with Xylazine Hydrocloride $(40 \mathrm{mg}$ / $\mathrm{kg} / \mathrm{IM}$ ) and Ketamine Hydrocloride (1 mg/kg/IV). Note the normal sinus rhythm, P wave, QRS complex and T wave, observed for females (A) and males (B).

\section{RESULTS}

Table 1 shows the results for the duration and amplitude of the $\mathrm{P}$ wave, duration of the QRS complex, duration of the QT interval and PR interval, and amplitude of the $\mathrm{R}$ wave and $\mathrm{T}$ wave. Table 2 shows the heart rate $(\mathrm{bpm})$ and weight $(\mathrm{kg})$.

For the duration of the $\mathrm{P}$ wave $(39.78 \pm 6.5 \mathrm{~ms}$ for males and $37.25 \pm 4.98 \mathrm{~ms}$ for females) and QT interval $(247.26 \pm 30.37 \mathrm{~ms}$ for males and $234.70 \pm$ $25.78 \mathrm{~ms}$ for females), when males and females were compared, there was no difference between means $(P<$ $0.05)$. Likewise, for the amplitude of the waves $\mathrm{P}(0.14$ $\pm 0.03 \mathrm{mV}$ for males and $0.12 \pm 0.03 \mathrm{mV}$ for females); $\mathrm{R}(0.42 \pm 0.31 \mathrm{mV}$ for males and $0.36 \pm 0.22 \mathrm{mV}$ for females $)$ and $\mathrm{T}(0.24 \pm 0.16 \mathrm{mV}$ for males and 0.25 $\pm 0.10 \mathrm{mV}$ for females) there was also not statistical difference $(P>0.05)$. T wave amplitude was predominantly negative (in 10 animals). In 8 animals, positive polarity was observed in DII derivation, but no biphasic configuration was observed in the present study.

The QRS complex presented duration of 46.14 $\pm 5.05 \mathrm{~ms}$ (males) and $44.66 \pm 5.94 \mathrm{~ms}$ (females) and the PR interval duration of $79.94 \pm 12.01 \mathrm{~ms}$ (males) and $84.29 \pm 12,37 \mathrm{~ms}$ (females), and no difference was found between the means.

Male heart rate averaged $113.25 \pm 5.1 \mathrm{bpm}$, while for females the value of $124.60 \pm 6.2 \mathrm{bpm}$ was observed, the difference between these values being statistically significant. The weight variable presented higher value for males $(2.31 \pm 0.2 \mathrm{~kg})$ than for females $(2.28 \pm 0.12 \mathrm{~kg})$, with no difference between means $(P>0.05)$.

Table 1. Duration and amplitude of the P wave, duration of the QRS complex, QT interval, PR interval and T wave. Results found for duration and amplitude of the R wave and T wave of agoutis (Dasyprocta prymnolopha), chemically contained with Ketamine Hydrocloride and Xylazine Hydrocloride. Teresina, Piauí, Brazil, 2017.

\begin{tabular}{|c|c|c|c|c|c|c|c|}
\hline Parameters & $\mathrm{P}(\mathrm{ms})$ & QRS (ms) & PR (ms) & QT (ms) & $\mathrm{P}(\mathrm{mV})$ & $\mathrm{R}(\mathrm{mV})$ & $\mathrm{T}(\mathrm{mV})$ \\
\hline Male & $\begin{array}{c}(39.78 \pm \\
6.5)^{\mathrm{a}}\end{array}$ & $\begin{array}{c}(46.14 \pm \\
5.05)^{\mathrm{a}}\end{array}$ & $\begin{array}{c}(79.94 \pm \\
12.01)^{\mathrm{a}}\end{array}$ & $\begin{array}{c}(247.26 \pm \\
30.37)^{\mathrm{a}}\end{array}$ & $\begin{array}{c}(0.14 \pm \\
0.03)^{\mathrm{a}}\end{array}$ & $(0.42 \pm 0.31)^{\mathbf{a}}$ & $(0.24 \pm 0,16)^{\mathbf{a}}$ \\
\hline Female & $\begin{array}{c}(37.25 \pm \\
4.98)^{\mathbf{b}}\end{array}$ & $\begin{array}{c}(44.66 \pm \\
5.94)^{\mathrm{a}}\end{array}$ & $\begin{array}{c}(84.29 \pm \\
12.37)^{\mathbf{a}}\end{array}$ & $\begin{array}{c}(234.70 \pm \\
25.78)^{\mathbf{b}}\end{array}$ & $\begin{array}{c}(0.12 \pm \\
0.03)^{\mathrm{a}}\end{array}$ & $(0.36 \pm 0.22)^{\mathbf{a}}$ & $(0.25 \pm 0,10)^{\mathbf{a}}$ \\
\hline$t$-Test & $\begin{array}{c}(P=0.023 ; \\
P>0.05)\end{array}$ & $\begin{array}{l}(P=0.16 \\
P>0.05)\end{array}$ & $\begin{array}{c}(P=0.064 \\
P>0.05)\end{array}$ & $\begin{array}{c}(P=0.021 \\
P>0.05)\end{array}$ & $\begin{array}{l}(P=0.02 \\
P>0.05)\end{array}$ & $(P=0.24 ; P>0,05)$ & $(P=0,88 ; P>0,05)$ \\
\hline
\end{tabular}


Table 2. Heart rate values in beats per minute ( $\mathrm{bpm}$ ) and weight ( $\mathrm{kg}$ ) of agoutis (Dasyprocta prymnolopha) chemically contained with Ketamine Hydrocloride and Xylazine Hydrocloride. Teresina, Piauí, Brazil, 2017.

\begin{tabular}{ccc}
\hline Parameter & hr $(\mathrm{bpm})$ & Weight $(\mathrm{kg})$ \\
\hline Male & $(113.25 \pm 29.40)^{\mathbf{a}}$ & $(2.31 \pm 0,22)^{\mathbf{a}}$ \\
Female & $(124.60 \pm 24.32)^{\mathbf{b}}$ & $(2.28 \pm 0,19)^{\mathbf{a}}$ \\
Student $t$-Test & $(P=0.03 ; P>0.05)$ & $(P=0.49 ; P>0.05)$ \\
\hline
\end{tabular}

\section{DISCUSSION}

Previous studies have demonstrated that the agoutis can be handled without previous chemical restraint for the performance of electrocardiographic exams, as it is a fast execution technique [7]. Wild animals, in general, need the implantation of anesthetic protocols, with the purpose of reducing stress during clinical-surgical and handling procedures, to avoid accidents with the animals and the people who handle them [4]. Knowing that prolonged stimuli of physical restraint can easily lead wild animals to death $[20,42]$, the protocols established in this work can be used in future experiments, which require a longer handling time.

The values found for heart rate (HR) of anesthetized agoutis with Ketamine and Xylazine (113.25 $\pm 29.40 \mathrm{bpm}$ for males and $124.60 \pm 24.32 \mathrm{bpm}$ for females) were lower than those found for this same non-anesthetized species $(193.42 \pm 25.39 \mathrm{bpm})$ [7]. These results suggest that such a difference may be related to stress during the physical restraint of nonanesthetized animals, leading to sinus tachycardia [13], or to the cardiovascular effects of Xylazine in sedated animals, which provoke a depression of the vasomotor center, increase of the vagal tone and of the baroreceptors activity, resulting in bradycardia $[31,44]$.

The HR of agoutis was smaller than that found in domestic species such as dogs and cats $[27,45]$ and wild species such as wolves, leopards and cheetahs $[10,34,41]$. HR is related to several factors such as age, sex, body position, respiration, functional capacity and characteristics in each species. Carnivorous animals, in general, present intense respiratory and energetic activity, which can affect the HR values when compared to rodents [30].

The $\mathrm{P}$ wave presented morphology and values, both in duration and in amplitude, very close to the parameters found for animals of the same species not anesthetized [7]. The amplitude of this wave showed no difference between the genders, whereas the duration showed statistical difference. There are no reports of this difference between genders in non-anesthetized agoutis [7]. Changes in the duration of the $\mathrm{P}$ wave may be related to variations in the size of animals of the same species as the dogs, where there is a diversity of races, differing in the size of the heart, thus affecting the time that the electrical impulse takes to depolarize the atria, resulting in the duration variations of this wave $[13,18]$. However, agoutis are fairly uniform external rodents, whose males do not differ from females visually [14]. In addition, the animals in this study presented similar weight, suggesting that the difference in the duration of this wave is probably related to some characteristic of the genre and not to the procedure of the examination.

The duration of the $\mathrm{P}$ wave of agoutis differed from the values found for non-anesthetized ferrets [9], however there was similarity in the values of this parameter for anesthetized ferrets [40]. In rabbits submitted to electrocardiography, there were morphologically different $\mathrm{P}$ waves in some breeds, but with no pathological significance [39].

The PR interval despite presenting higher values for females was not statistically significant, as was described for humans [37] and ferrets [9]. The PR interval may vary discreetly due to changes in vagal tone [16]. Also, changes in this interval may occur due to electrical impulse conduction disorders through the atrioventricular node and/or its region, in elderly animals with degenerative changes, or due to increased vagotonic effects [45]. The state of sanity, being young animals, besides the similar morphology of the animals of this study justifies the small variations in the PR interval and the similarity between the genders.

The duration of the QT interval was higher for males, and statistically significant differences were observed when comparing the genders. These values were lower than the human standard (360 ms) [37] and higher than that found for wild cats (Leopardus tigrinus) (230 ms), which did not show differences between males 
and females [34]. This interval represents the complete duration of the ventricular electrical activity, and may be influenced by heart rate variations, in this case, showing a proportionally inverse relationship between the two parameters [35]. The QT interval for non-anesthetized agoutis was lower than for anesthetized agoutis. This interval is strongly influenced by the sympathetic nervous system [13]. Studies suggest that the HR and the QT interval are controlled separately by different neuronal fibers, which may or may not be concomitantly activated. During exercise or stress, the QT interval decreases due to the natural production of catecholamines, justifying the differences in these values found for anesthetized and non-anesthetized agoutis [45]. In humans, this time is lower than several animal species such as dogs [47], rabbits [26] and non-anesthetized agoutis [7], being an indication of need of early repolarization for animals. This interval was shown to be smaller than for humans. However, changes in the QT interval hardly present clinical repercussion in animals, as occurs in humans, such as situations of hypothermia or hypercalcemia [22].

The QRS complex duration differences were statistically the same between genders, although the values for males were slightly higher than for females. This uniformity suggests an anatomical and topographic similarity of the thoracic organs of agoutis [14], although anatomical studies in this species are scarce. Some authors suggest that changes in the position of the diaphragm may lead to a change in the QRS complex. In animals, this can be observed when gastric content is present at the time of examination, which can displace the diaphragm by pressing the thoracic cavity to allow electrocardiographic changes [43]. However, in this experiment all animals were prepared to solid fasting for $12 \mathrm{~h}$ and water fasting for 6 hours before the tests, which allowed a greater uniformity in the findings which justifies the results found.

In this experiment, values for $\mathrm{T}$ wave amplitude, although higher for females, were statistically the same when comparing genders. For non-anesthetized agoutis, values for $\mathrm{T}$ wave amplitude were higher in males [7]. In addition, the $\mathrm{T}$ wave of the males of this experiment corresponded to approximately $57 \%$ of the previous $\mathrm{R}$ wave, while for the females, it corresponded to approximately $69 \%$. When compared to non-anesthetized agoutis, the $\mathrm{T}$ wave of males reached almost $100 \%$ of the previous $\mathrm{R}$ wave size and in females this value reached $70 \%$. T wave amplitude values for other animal species of the same size as non-anesthetized rabbits were about 50\% lower than those found in this experiment. In contrast, non-anesthetized ferrets presented a value close to that of anesthetize agoutis $[9,26]$. This relationship is well studied in dogs and cats and it is considered that the $\mathrm{T}$ wave can measure up to $25 \%$ of the $\mathrm{R}$ wave in these species. Above this percentage, the $\mathrm{T}$ wave may indicate processes of myocardial hypoxia or electrolytic imbalances [45].

In humans, high T-wave amplitudes are thought to occur in $2.5 \%$ to $14 \%$ of adult individuals with no evidence of cardiovascular or extra-cardiac diseases [25], however, it is one of the parameters taken into consideration in the suspicion of myocardial infarction. Myocardial ischemia is more tolerated in animals than in humans and may be due to factors such as stress and exaggerated physical activity, as observed in the species in question. A change caused using drugs such as Ketamine, as described in studies with dogs and primates $[4,6,33]$ is not excluded.

The T-wave morphology was varied in the aspect of polarity. However, this characteristic is usually observed in other species and therefore authors suggest the evaluation of previous electrocardiograms of the same animal [18].

The evaluation of the cardiac muscle lesion due to the reduction of oxygen requires more in-depth imaging studies, however, with the present study, it can be affirmed that agoutis sedated with ketamine and xylazine tolerate well a reduction in the amount of oxygen destined to the myocardium, since all animals were well recovered and did not present clinical symptoms after the anesthetic procedure. In addition, it is possible to suggest that the chemical contention generates less cardiac oxygenation than the physical contention, since in the present study the $\mathrm{T}$ wave amplitude values were smaller compared to the $\mathrm{R}$ wave, than $\mathrm{T}$ wave amplitudes produced in non-anesthetized agoutis [7].

\section{CONCLUSION}

The chemical containment protocol used in this experiment was well tolerated by the animals and the effects of the drugs showed no risk during the procedure. Thus, the data described here for the electrocardiographic pattern of agoutis (Dasyprocta prymnolopha) can be used to monitor these animals in anesthetic procedures with Ketamine and Xylazine. We hope, therefore, to collaborate with the rational handling, conservation and biodiversity of these animals. 
MANUFACTURERS

${ }^{1}$ Laboratorios Konig As. Buenos Aires, Argentina.

${ }^{2}$ Bayer S.A. São Paulo, SP, Brazil.

${ }^{3}$ Brazilian Electronic Technology (TEB). São Paulo, SP, Brazil.

Acknowlegments. The authors thank the Diagnosis by Image Sector of the University Veterinary Hospital, UFPI for making the animals available. They also thank the Coordination for the Improvement of Higher Education Personnel (CAPES), for the master degree grant.
Ethical approval. This research was performed after evaluation and approval of the Committee on Ethics in Animal Experimentation of the Federal University of Piauí, with protocol No $0117 / 2010$.

Declaration of interest. The authors report no conflicts of interest. The authors alone are responsible for the content and writing of the paper.

\section{REFERENCES}

1 Allen D.G. \& Downey R.S. 1983. Echocardiographic assessment of cats anesthetized with xylazine-sodium pentobarbital. Canadian Journal Compendium. 47(3): 281-283.

2 Bone L., Battles A.H., Goldfarb R.D., Lombard C.W. \& Moreland A.F. 1988. Electrocardiographic values from clinical normal, anesthetized ferrets (Mustela putorious furo). American Journal of Veterinary Research. 49(1): 1884-1887.

3 Booth N.H. 1992. Anestésicos intravenosos e outros parenterais. In: Booth N.H. \& Mcdonald L.E. (Eds). Farmacologia e terapêutica em veterinária. 6.ed. Rio de Janeiro: Guanabara Koogan, pp.168-218.

4 Bublot I.R., Chalvet-Monfray K. \& Edwards N.J. 2006. The surface electrocardiogram in domestic ferrets. Journal of Veterinary Cardiology. 8(2): 87-93.

5 Carvalho S.F.M. \& Santos A.L.Q. 2006. Valores das ondas do eletrocardiograma de Tartarugas-da- Amazônia (Podocnemis expansa, Schweigger, 1812) (testudines). ARS Veterinária. 22(1): 117-121.

6 Clark D.M., Martin R.A. \& Short C.A. 1982. Cardiopulmonary responses to xylazine/ketamine anesthesia in dog. Journal of the American Animal Hospital Association. 18(2): 815-821.

7 Diniz A.N., Silva-Júnior J.R., Ambrósio C.E., Sousa J.M., Sousa V.R., Carvalho M.A.M., Nascimento D.N. \& Alves F.R. 2013. Thoracic and heart biometrics of non-anesthetized agouti (Dasyprocta primnolopha, Wagler, 1831) measured on radiographic images. Pesquisa Veterinária Brasileira. 33(3): 411-416.

8 Diniz L.S. 1996. Imobilização química em animais silvestres. In: Spinosa H.S., Gorniak S.L. \& Bernardi M. (Eds). Farmacologia Aplicada à Medicina Veterinária. 5th edn. Rio de Janeiro: Guanabara Koogan, pp.153-163.

9 Dudás-Györki Z., Szabó Z., Manczur F. \& Vörös K. 2011. Echocardiographic and electrocardiographic examination of clinically healthy, conscious ferrets. Journal of Small Animal Practice. 52(1): 18-25.

10 Estrada A.H., Gerlach T.J., Schmidt M.K., Siegal-Willott J.L., Adrienne L., Atkins A.L., Scott B., Citino S.B. \& Padilla L.R. 2009. Cardiac evaluation of clinically healthy captive maned wolves, Chrysocyon brachyurus. Journal of Zoo and Wildlife Medicine. 40(3): 478-486.

11 Fantoni D.T. \& Cortopassi S.R.G. 2002. Anestesia em Cães e Gatos. 2.ed. São Paulo: Roca, 389p.

12 Felippe P.A.N. 2007. Eletrocardiografia. In: Cubas Z.S., Silva J.C.R. \& Catão-Dias J.L. (Eds). Tratado de animais selvagens medicina veterinária. SãoPaulo: Roca, pp.920-929.

13 Filippi L.H. 2011. O eletrocardiograma na medicina veterinária. São Paulo: Roca, 160p.

14 Fortes E.A.M., Ferraz M.S., Bezerra D.O., Conde Júnior A.M., Cabral R.M., Sousa F.C.A., Almeida H.M., Pessoa G.T., Menezes D.J.A., Guerra S.P.L., Sampaio I.B.M., Assis-Neto A.C. \& Carvalho M.A.M. 2013. Prenatal development of the agouti (Dasyprocta prymnolopha, Wagler, 1831): External features and growth curves. Animal Reproduction Science. 140(3): 195-205.

15 Fox M., Brieva C., Moreno C., Macwilliams P. \& Thomas C. 2008. Hematologic and Serum Biochemistry Reference Values in Wild-Caught White-Footed Tamarins (Saguinus leucopus) Housed in Captivity. Journal of Zoo and Wildlife Medicine. 39(4): 548-557.

16 Goodwin J. \& Tilley L.T. 2001. Manual of canine and feline cardiology. 5th edn. Philadelphia: WB Saunders, 300p.

17 Green C.J., Knight J., Precious S. \& Simpkin S. 1981. Ketamine alone and combined with diazepam or xylazine in laboratory animals: a 10 year experience. Laboratory Animals. 15(2): 163-17.

18 Hamlin R.L. \& Smith C. R. 1960. Anatomical and physiologic basis for interpretation of the electrocardiogram. American journal of veterinary research. 21(1): 701-708.

19 Hosken F.M. 2001. Manejo de Cutias. In: Hosken F.M. \& Silveira A.C. (Eds). Criação de Cutias. Viçosa: Aprenda Fácil, pp.21-22. 
20 Hunsley M.Z. 2011. Restraint and distress in wild mice: further modification recommended. Laboratory Animal. 40(6): 174-184.

21 Jacobs G. \& Knight D.H. 1985. Change in M-mode echocardiographic values in cats given ketamine. American Journal of Veterinary Reseach. 46(8): 1712-1713.

22 Kaese S. \& Verheule S. 2012. Cardiac electrophysiology in mice: A matter of size. Frontiers in Physiology. 3(1): 345.

23 Kligfield P., Gettes L.S. \& Bailey. 2007. Recommendations for the standardization and interpretation of the electrocardiogram. Part 1: the electrocardiogram and its technology. Circulation. 13(3): 1306-1324.

24 Kossmann C.E. 1953. The normal electrocardiogram. Circulation. 8(1): 920-936.

25 Lazzoli J.K., Castro C.L.B., Nóbrega A.C.L. \& Araújo C.G.S.A. 2002. Não existe eletrocardiograma de repouso de 12 derivações: uma análise com curvas ROC. Revista Brasileira de Medicina do Esporte. 8(4): 50-58.

26 Lord B., Boswood A. \& Petrie A. 2010. Electrocardiography of the normal domestic pet rabbit. Veterinary Record. 167(25): 961-965.

27 Martin M. 2002. ECG interpretation in small animals: practical guidelines. In Practice. 24(5): 250-261.

28 Martin M.W.S. 1995. Small animal echocardiography. In: Goddard P.J. (Ed). Veterinary Ultrasonography. Wallingford: Cab International, pp.131-165.

29 Massone F. 2003. Anestesiologia Veterinária: Farmacologia e Técnicas. 4.ed. Rio de Janeiro: Guanabara Koogan, 326 .

30 Migliaro E.R., Contreras P., Bech S., Etxagibel A., Castro M., Ricca R. \& Vicente K. 2001. Relative influence of age, resting heart rate and sedentary life style in short-term analysis of heart rate variability. Brazilian Journal of Medical and Biological Research. 34(4): 493-500.

31 Muir W.W. \& Gaynor J.S. 2015. Handbook of veterinary pain management. 2nd edn. St. Louis: Mosby Elsevier, $641 \mathrm{p}$.

32 Nogueira-Filho S.L.G. \& Nogueira S.S.C. 2000. Criação comercial de animais silvestres: produção e comercialização da carne e de subprodutos na região sudeste do Brasil. Revista Econômica do Nordeste. 31(2): 188-195.

33 Nunes N., Camacho A.A. \& Costa J.L.O. 1997. Eletrocardiographic study of the anesthetic combination of ketamine and chlorpromazine HCL in felines. Brazilian Journal of Veterinary Research and Animal Science. 34(1): 313-316.

34 Oda S.G.S., Yamat R.J., Fedullo J.D.L., Leomil Neto M. \& Larsson M.H.M. 2009. Standardization of some electrocardiographic parameters of captive leopard cats, Leopardus tigrinus. Journal of Zoo and Wildife Medicine. 40(3): 414-420.

35 Oliveira M.S., Muzzi R.A., Muzzi L.A., Cherem M. \& Mantovani M.M. 2014. QT interval in healthy dogs: which method of correcting the QT interval in dogs is appropriate for use in small animal clinics ? Pesquisa Veterinária Brasileira. 34(5): 469-472.

36 Orutt C.J. 2000. Cardiac and respiratory disease in rabbits. Proceedings of the British Veterinary Zoological Society. 11(1): 68-73.

37 Pastore C.A., Pinho J.A., Pinho C., Samesima N., Pereira-Filho H.G., Kruse J.C.L., Paixão A., Pérez-Riera A.R., Ribeiro A.L., Oliveira C.A.R., Gomes C.I.G., Kaiser E., Galvão F., Darrieux F.C.C., França F.F.A.C., Feitosa-Filho G, Germiniani H, Aziz J.L., Leal M.G., Molina M, Oliveira N.M.T., Oliveira P.A., Sanches P.C.R., Almeida R.M., Barbosa R., Teixeira R.A., Douglas R.A.G., Gundim R.S. \& Atanes S.M. 2016. III Diretrizes da Sociedade Brasileira de Cardiologia sobre Ánalise e Emissão de Laudos Eletrocardiográficos. Arquivos Brasileiros de Cardiologias. 106(4): 3-15.

38 Prado-Filho O.R., Steffens V.A., Santos B.A., Lukiantchuki L.P.A. \& Moreira R.P. 2000. Xilazina como prémedicação para anestesia com tiopental sódico em cães. Acta Cirurgica Brasileira. 15(2): 2-8.

39 Reusch B. 2005. Investigation and management of cardiovascular disease in rabbits. In Practice. 27(1): 418-25.

40 Schoemaker N.J. \& Zandvliet M.M. 2005. Electrocardiography in Psittacine birds and ferrets. Seminaris in Avian and Exotic Pet Medicine. 14(2): 34-51.

41 Schumacher J., Snyder P., Scott B., Citino S.B., Bennett R.A. \& Dvorak L.D. 2003. Radiographic and electrocardiographic evaluation of cardiac morphology and function in captive cheetahs Acinonyx jubatus. Journal of Zoo and Wildlife Medicine. 34(4): 357-363.

42 Shukan E. \& Hitt N. 2011. Restraint and distress in wild mice: perhaps a pilot study. Labortory Animals. 40(6): 173 183. 
O.F. Silva Filho, G.T. Pessoa, R.P.S. Rodrigues, et al. 2017. Electrocardiographic Pattern of Agoutis (Dasyprocta prymnolopha) Chemically Contained by the Association of Ketamine and Xylazine. Acta Scientiae Veterinariae. 45: 1460.

43 Slapak L. \& Hermanek P. 1957. Observations on the electrocardiogram of rabbits. Zeitschrift für Kreislaufforschung. 46(3-4): 136-142.

44 J.C., Tranquilli W.J. \& Benson C.J. 1999. Essentials of Small AnimalAnesthesia \& Analgesia. Philadelphia: Lippincott Williams \& Wilkins, 580p.

45 Tilley L.P. 1992. Essential of canine and feline electrocardiography. 2nd edn. Philadelphia: Lea \& Febiger, 470p.

46 Zandvliet M.J.M. 2005. Electrocardiography in psittacine birds and ferrets. Seminars In Avian and Exotic Pet Medicine. 14(1): 34-51.

47 Wolf R., Camacho A.A. \& Souza R.C.A. 2000. Eletrocardiografia computadorizada em cães. Arquivo Brasileiro de Medicina Veterinária e Zootecnia. 52(6): 610-615. 